\title{
VETTING BILLS IN THE SCOTTISH PARLIAMENT FOR LEGISLATIVE COMPETENCE
}

\author{
CHRISTOPHER MCCORKINDALE* \\ JANET HIEBERT**
}

\section{A. Introduction}

Unlike Acts of the United Kingdom Parliament, primary legislation made by the Scottish Parliament is not immune from judicial review. ${ }^{1}$ The devolved legislature is a parliament of limited competence, the boundaries of which are found in both statute and the common law. Accordingly, an Act of the Scottish Parliament (ASP) "is not law" in so far as, inter alia, it "relates to" a reserved matter, or is incompatible with a Convention right or with EU law, ${ }^{2}$ and, in extreme circumstances, it is also invalid to the extent that it violates the fundamental principle(s) of the rule of law. ${ }^{3}$ Where the Parliament does legislate beyond those limits, courts have the power to set aside the offending Act.

For those engaged in the law-making process - from civil servants, to legislators, to courts, to those public bodies and private actors who rely on the rights and duties conferred by legislation the consequences of legislating beyond the Parliament's competence are therefore severe, for a number of reasons. First, there is a clear risk of reputational damage both to the Scottish Government and to the Scottish Parliament where legislation is found to be defective. Second, because an Act might have been in force for some time, or have been widely and deeply relied upon, there may be uncertainty in the obligations arising from devolved legislation at least until such time as the matter has been settled by a court. Third, there are serious concerns for the Scottish Government if elements of its legislative agenda face delay and defeat. These concerns are not restricted to the inability to pursue and implement key policies but can have broader political and electoral effects for a government that is perceived to be failing to deliver its promises. Fourth, there is an associated remedial cost both in terms of the parliamentary time required to cure defective legislation and in terms of damages or other remedies that might arise as a result of an adverse judicial ruling. Finally, there is a possibility that courts themselves might suffer reputational damage where they are perceived to have overstepped the mark in striking down primary legislation passed by a democratically elected legislature. ${ }^{4}$

\footnotetext{
${ }^{1}$ On the status of Acts of the Scottish Parliament see A McHarg, "What is delegated legislation?" [2006] PL 539.

2 Scotland Act 1998 s 29.

${ }^{3}$ AXA General Insurance v Lord Advocate [2011] UKSC 46, 2012 SC (UKSC) 122 at paras $42-52$ per Lord Hope, and paras 136-154 per Lord Reed. Suggested examples of sufficiently extreme legislation includes: legislation which aims to abolish judicial review or to diminish the role of the courts in protecting individual rights (Lord Hope at para 51) or which seeks to curtail the franchise in order to entrench the power of a parliamentary majority (Moohan v Lord Advocate [2014] UKSC 67, 2015 SC (UKSC) 1 at para 35 per Lord Hodge).

${ }^{4}$ Whilst the political reaction to adverse rulings about legislative competence has so far been measured, the opportunity for friction was highlighted by the criticisms made of the Supreme Court's influence by the then First Minister, Alex Salmond, and Justice Secretary, Kenny MacAskill, following adverse rulings by the Supreme Court in relation to aspects of Scots criminal law. On the political reaction to Cadder see A Trench, "The Cadder case and legal advice for suspects in Scotland" (28 October 2010) Devolution Matters blog, available at: $<$ https://devolutionmatters.wordpress.com/2010/10/28/the-cadder-case-and-legal-advice-for-suspects-inscotland/> as well as the relevant links therein. For a detailed treatment of the legal issues which arose in -
} 
In order to protect legislation against this vulnerability the Scotland Act 1998 established a framework of pre-enactment checks and cross-checks which engage the Scottish Government ${ }^{5}$ with both the Scottish Parliament and the UK Government in the exercise of vetting Bills for legislative competence:

(1) On or before the introduction of a Bill, the responsible Minister must report to Parliament that in his or her view the Bill is within the Parliament's legislative competence; ${ }^{6}$

(2) On or before the introduction of a Bill, the Presiding Officer must report to Parliament his or her view as to whether or not the Bill is within the Parliament's legislative competence; ${ }^{7}$

(3) Following the completion of the Bill's parliamentary stages, the Presiding Officer must withhold submission of the Bill for Royal Assent for four weeks, ${ }^{8}$ during which period the Scottish and UK Law Officers - the Lord Advocate on behalf of the Scottish Government, and the Advocate General for Scotland and the Attorney General on behalf of the UK Government - may refer the question of legislative competence directly to the Supreme Court. $^{9}$

In this article we examine the ways in which these institutions have engaged internally and with one another in the process of vetting Bills for legislative competence during the first four parliamentary sessions (1999-2016). By shedding light on a process that generally is concealed behind private discussions and legal confidentiality (what Alan Trench has called "a form of private public law") $)^{10}$ we will see (1) why it is that - contrary to early warnings that strong judicial review might make Scotland's "a constitution of judges"11 - (successful) legal challenges to the competence of legislation have proved to be the exception rather than the rule, and (2) why it is that, despite this network of checks, legislation might nevertheless remain at risk of judicial censure.

To understand the complex processes which constitute this exercise we interviewed more than twenty officials, advisers and politicians currently or formerly in the Scottish Government, Scottish Parliament and UK Government. ${ }^{12}$ During the course of our interviews officials who have been involved at each of the distinct vetting points stressed to us their commitment (and the faith that they have in the commitment of counterparts across those institutions) to make devolution work. Moreover, officials stressed to us that serious disagreement about legislative competence is a relatively (though not an insignificantly) rare occurrence during the legislative process, perhaps

and which flowed from - this landmark case see the special issue on Cadder in (2011) 15(2) Edinburgh Law Review.

${ }^{5}$ In fact, section 6 of the Scotland Act 2012 extended this obligation to any person in charge of a Bill (including, inter alia, MSPs introducing Members' Bills or convenors introducing Committee Bills). This study, however, is concerned with scrutiny of the executive and so our focus in this article is on Government Bills.

${ }^{6}$ SA 1998 s31(1).

${ }^{7}$ SA 1998 s31(2).

8 ibid.

${ }^{9}$ SA 1998 s33.

${ }^{10}$ Memorandum submitted to the House of Commons Justice Committee's inquiry Devolution: A Decade On inquiry (April 2007), available at $<$ http://www.publications.parliament.uk/pa/cm200809/cmselect/cmjust/529/529we15.htm>.

${ }^{11}$ A O'Neill, "Parliamentary Sovereignty and the Judicial Review of Legislation", in A McHarg and T Mullen (eds), Public Law in Scotland (2006) 197.

${ }^{12}$ These interviews were conducted on the basis of anonymity, and (mostly) took place during the month of September 2015. 
arising once or twice during an average year. However, and this commitment notwithstanding, these interviews revealed differences within and across those institutions both with regard to how competence assessments are made and with regard to the expectations and anxieties of each as they engage in the process.

The first part of the article focuses on the conceptual argument that, despite the strong form of judicial review that applies to Acts of the Scottish Parliament, the decision to require legislative review of every Bill for its constitutional quality aligns the devolution scheme with those political systems which - in different ways - combine Westminster-style parliamentary government with judicially enforceable constitutional boundaries. Whilst these have been developed in the specific context of rights review we shall see that the Scottish variant augments these models in two senses: first, by applying legislative review to a broader set of constitutional considerations (namely EU law and the boundary between reserved and devolved matters); second, by multiplying and varying the points at which Bills are subject to legislative review. The second part of the article supports this conceptual argument with an empirical examination of the ways in which assessments about legislative competence are made by and between the Scottish Government, the Scottish Parliament and the UK Government.

\section{B. Legislative review: a third way}

In recent years public law scholarship has sought to describe, and to defend, an alternative or "third way" of constitutionalism. This approach builds upon (rather than breaks with) antecedent models of legislative or judicial supremacy, in which either parliament or the courts have the last word on the legality of legislation. ${ }^{13}$ Two fundamental characteristics distinguish this alternative approach. One is constrained judicial remedial powers. For Westminster-based parliamentary systems, the very idea of introducing a judicially-enforceable bill of rights represents a fundamental departure from previously held assumptions that such instruments clash with the core constitutional principle of parliamentary supremacy. However, by distinguishing between judicial review and judicial remedies, it is possible to retain parliament's last word on the validity of legislation. The second fundamental characteristic is that this approach envisages a far more important role for rights review at the legislative stage than is usually associated with a bill of rights. By placing a statutory obligation on the executive to report to parliament when a Bill is inconsistent with rights this particular legislative focus reflects the following three ideals: ${ }^{14}$ identifying whether and how proposed legislation implicates rights; encouraging more rights-compliant ways of achieving legislative objectives (and in the extreme discourage the pursuit of objectives that are fundamentally incompatible with rights); and facilitating parliamentary deliberation about whether legislation implicates rights, thereby

\footnotetext{
${ }^{13}$ See for example, S Gardbaum, The New Commonwealth Model of Constitutionalism: Theory and Practice (2013); J Goldsworthy, "Homogenizing constitutions" (2003) 23 OJLS 482; M Tushnet, Weak Courts, Strong Rights. Judicial Review and Social Welfare Rights in Comparative Constitutional Law (2008); G Williams, "The Victoria Charter of Human Rights and Responsibilities: origins and scope" (2006) 30 MULR 880; F Klug, Values for a Godless Age: The Story of the United Kingdom's New Bill of Rights (2000).

${ }^{14}$ These reporting obligations vary. Some are made by the Attorney General (New Zealand, ACT) or Justice Minister (Canada), whereas others are made by the sponsoring minister (UK and Victoria); some include only government Bills (Canada, UK); and some require reports only for inconsistency (Canada, New Zealand) whereas others report both affirmative and negative reports of compatibility (UK, ACT and Victoria).
} 
increasing parliament's capacity to pressure government to justify, alter or abandon legislation that unduly infringes rights. ${ }^{15}$

\section{(1) Judicial supremacy revisited}

In some respects Scotland's devolution scheme is a neat fit with the model of judicial supremacy. First, the Scottish Parliament is not a sovereign legislature but one for which constitutional limits have been enshrined in statute. This is so not only because it is a subordinate legislature, itself constituted and limited by an Act of Parliament, ${ }^{16}$ but also because it was an aspiration of its framers that the new Parliament should distinguish itself from Westminster on the question of sovereignty. As Bernard Crick and David Millar said:

The concept of sovereignty...is a product of a by-gone age when unchallengeable central power seemed to many (as in 1707) the only answer to continual civil war. National identity does not depend upon a belief in sovereign power rather than in a more pluralistic, constitutionalised account of power, defined and limited by law. A Scottish Parliament, however elected, needs limiting as...much as any other. ${ }^{17}$

As Lord Rodger would later recognise, with regard to the question of unlimited legislative supremacy Westminster is the exception rather than the rule. The Scottish Parliament, he said, "has simply joined that wider family of parliaments" who "even where [they] have been modelled in some respects on Westminster [nevertheless] owe their existence and powers to statute and are in various ways subject to law and the courts which act to uphold the law."18

Second, it is the UK Supreme Court, and not the Scottish Parliament, that has the final word on whether an Act of the Scottish Parliament is law. Indeed, Lord Neuberger, the President of the Supreme Court, has said that this power over devolved competence bestows upon that court some of the characteristics of a constitutional court. Just as in a country with a codified constitution "the Supreme Court (as in the US) or the Constitutional Court (as in Germany) can, indeed must, strike down legislation which has been enacted by the democratically elected parliament if the court concludes that the legislation does not comply with the Constitution," he said, so too the Supreme Court must strike down any legislation that has passed through the democratically elected devolved legislatures if the Court concludes that it falls outwith legislative competence as defined in statute. ${ }^{19}$ Third, officials across the Scottish Government, the Scottish Parliament and the UK Government confirmed to us that their method for assessing competence is driven by the devolution jurisprudence of the Supreme Court. In this way judicial norms might impact upon Bills as they pass

\footnotetext{
${ }^{15} \mathrm{~J}$ Hiebert and J Kelly, Parliamentary Bills of Rights: The Experiences of New Zealand and the United Kingdom (2015) 1-6.

${ }^{16}$ Imperial Tobacco, Petitioner [2012] CSIH 9, 2012 SC 297 at paras 58 and 71 per Lord Reed.

${ }^{17}$ B Crick and D Millar, To Make the Scottish Parliament a Model for Democracy (1991) 9.

${ }^{18}$ Whaley $v$ Watson 2000 SC 340 at 349 per Lord Rodger.

${ }^{19}$ Lord Neuberger, "The UK Constitutional Settlement and the UK Supreme Court" (10 October 2014) speech at the Legal Wales Conference 2014, available at https://www.supremecourt.uk/docs/speech-141010.pdf.
} 
through the policy development, pre-introduction and parliamentary stages even if the resulting legislation is never made subject to a legal challenge..$^{20}$

In Stepehen Gardbaum's account, this factor alone - that the Supreme Court has the final say on the legality of legislation - would be sufficient to exclude the Scotland Act scheme from this socalled "third way". Parliament's retention of the last word is, for Gardbaum, the defining feature of what he labels as the "New Commonwealth model of constitutionalism".${ }^{21}$ In our view, however, it is the reporting obligation and the impact that this has on legislative decision-making that distinguishes the "third way" in a way that captures law-making in the Scottish Parliament. The Scotland Act 1998 is fitted with mechanisms that were designed to enhance the legislative review of every Bill for legislative competence. Some of these mechanisms - the reporting obligation placed on the sponsoring Minister and the significant role given to the Scottish Government's Law Officers are typical of these models. In addition to internal checks by the executive, however, the mechanisms for legislative review are strengthened in the devolved setting by external cross-checks on the Government's legislative agenda both by the Parliament, through the simultaneous reporting requirement placed on its Presiding Officer, and by the UK Government, whose Law Officers engage with questions of legislative competence before a Bill is submitted for Royal Assent.

\section{(2) The role of the Scottish Government}

Upon the introduction of a Bill, section 31(1) of the Scotland Act requires the responsible Minister to report to the Scottish Parliament his or her view that it would be within legislative competence. The purposes of this provision are simultaneously inward and outward facing. On the one hand the ministerial reporting requirement serves to ensure that the Scottish Government "has properly considered the issue and made a proper judgement...that the measure is within the power and competence of the Scottish Parliament,"22 a view, it was said (and so it has proved), that would be reached on basis of legal advice (offered by the Scottish Government Legal Directorate (SGLD) and by the Lord Advocate). ${ }^{23}$ On the other hand, it serves to enhance legislative scrutiny, informing Parliament so that - as the Bill makes its way through the chamber - its members may "ask questions about the statement, raise queries as to whether it is entirely correct, and no doubt identify particular provisions in the Bill where there may or may not be some doubt as to whether the provisions lie within the legislative competence."24

\section{(3) The role of the Scottish Parliament}

In contrast to the Human Rights Act scheme, the operation of which is enhanced by the work of a specialist parliamentary committee - the Joint Committee on Human Rights - the ministerial reporting requirement contained in the Scotland Act has not been augmented with a specialist

\footnotetext{
${ }^{20}$ For a review of the Supreme Court's role in the devolution settlement see JS Caird and H Armstrong, The Supreme Court on Devolution (27 July 2016) House of Commons Library Research Paper 07670, available at http://researchbriefings.parliament.uk/ResearchBriefing/Summary/CBP-7670.

${ }^{21}$ Gardbaum, The New Commonwealth Model of Constitutionalism (n 13).

${ }^{22}$ HL Deb 28 July 1998, col 1353 per Baroness Ramsay of Cartvale.

${ }^{23} \mathrm{Ibid}$, col 1350 per Lord Mackay of Drumadoon.

${ }^{24} \mathrm{Ibid}$.
} 
committee tasked with scrutinising Bills for legislative competence. ${ }^{25}$ Instead, we were told that legislative competence is everyone's business, and for this reason (as well as for the workload implications for already stretched MSPs) little appetite was shown by Government or Parliament officials for the streamlining of competence considerations through a specialist committee. ${ }^{26}$ Rather, Parliament most directly engages with the question of competence through its Presiding Officer who at the introduction of a Bill must also report on the question of legislative competence.

This function is unique to (albeit that it differs slightly across) the UK's devolution schemes. Its purposes, as set out by Lord Sewel - the Minister of State in the Scottish Office responsible for steering the Scotland Bill through the House of Lords - are again two-fold. On the one hand, it serves to provide Parliament with "important guidance about the competence of the Parliament" that might serve to inform the subsequent scrutiny of a Bill. On the other, it provides the Presiding Officer with an opportunity "to express his concerns [to Parliament and to the Government] if he has any. ${ }^{27}$ As with the ministerial reporting requirement the view of the Presiding Officer is reached on the basis of legal advice, in this instance offered by the Office of the Solicitor to the Scottish Parliament (OSSP) whose role it is also, inter alia, to support the work of the Scottish Parliament's various committees.

\section{(4) The role of the Law Officers}

Legislative review in the Scottish Parliament is further enhanced by the statutory function of the Law Officers who, during the statutory four week period that follows the completion of a Bill's parliamentary stages, may refer a question of competence directly to the Supreme Court. ${ }^{28}$ If no reference is made, or if the Court upholds the validity of the legislation, the Bill will then be submitted for Royal Assent. Whilst superficially this might strengthen the view that the devolution scheme is a model of judicial supremacy - here, after all, is a direct and potentially fatal route for legislation to find its way before the Supreme Court - the consequence of the Court holding that a Bill is not within competence is to return the question to the legislative process. In this situation the Parliament must be given the opportunity to reconsider the Bill in light of the Court's decision and to make such amendments as might be necessary in order to bring it within competence. ${ }^{29}$ This is no "notwithstanding clause" (the power of the legislature to temporarily pre-empt or set aside the effects of otherwise binding judicial rulings, as seen in section 33 of the Canadian Charter of Rights and Freedoms): the Scottish Parliament has no power explicitly to legislate outwith competence at the reconsideration (nor at any other) stage; and the amended Bill might itself be referred to the Court if competence concerns persist. Nevertheless, by putting the Court in dialogue with Parliament before the Bill is enacted, the reference procedure intends (although this has yet to be tested in practice) to enhance the role of the legislature in the exercise of its scrutiny function.

(5) Westminster factors

\footnotetext{
${ }^{25}$ In the fifth session (2016-2021) what was previously the Finance Committee has taken on an additional constitutional brief, and has been renamed the Finance and Constitution Committee.

${ }^{26}$ For a critique of this position see B Adamson, "The protection of human rights in the legislative process in Scotland" in M Hunt, H Hooper and P Yowell. Parliaments and Human Rights: Redressing the Democratic Deficit (2015) ch 13.

27 HL Deb 9 Nov 1998, col 532.

${ }^{28}$ SA 1998 s33.

${ }^{29}$ SA 1998 s36(4).
} 
Models of legislative review seek to embed in Westminster systems the duty to think politically about constitutional boundaries within and across institutions. However, there are reasons inherent to that form of government to be cautious about their transformative potential. These "Westminster" factors include executive dominance of parliament and the centrality of political parties in structuring how parliament votes. On the one hand, members of a governing party vote in a cohesive manner and only infrequently vote against their party at levels significant enough to harm the passage of the government's legislative agenda. On the other, opposition party leaders typically do not embrace the merits of a compatibility-based framework as part of their strategic arsenal. ${ }^{30}$ Thus, governments have incurred weak pressure from parliament to explain how or why they believe Bills overstep constitutional boundaries; a failure all the more significant because of governments' apparent willingness to proceed with legislation that advisers indicate might face a high risk of judicial censure. ${ }^{31}$

Moreover, the norms implicit in the statutory reporting obligation have not yet displaced governments' more immediate interest, which is how to protect their legislative agendas from parliamentary delay, substantive amendments, or defeat. Acknowledging that a Bill oversteps the mark could enhance pressure to accept legislative amendments, which can weaken compromises that have already been undertaken within and across party lines, wreak havoc in an already crowded parliamentary agenda, and portray the government as weak for having been seen to give in to opposition pressures. ${ }^{32}$

Despite the intention that the Scottish Parliament would be "different" from Westminster indeed, that Westminster would be a "negative model" for the new legislature ${ }^{33}$ - these constraining factors persist. It is still the case, as Page has said, that "Westminster assumptions about the exercise of legislative power continue to hold sway." ${ }^{34}$ First, the vast majority of Bills and amendments passed during the first four parliamentary sessions were introduced by the executive, with little evidence yet of the legislative initiative being shared more widely with the Parliament. ${ }^{35}$ Second, studies have shown that the coalition (1999-2003; 2003-2007) and minority governments (2007-2011) behaved similarly in terms of loyalty, discipline and cohesion to single party majorities of the Westminster kind, before the election of a single party majority in the fourth session (20112016). ${ }^{36}$ Finally, during the course of our interviews we were repeatedly told that Ministers and backbench or opposition MSPs rarely second guess the legal assessments of competence made by legal advisers and, where competence issues do arise during the process of legislative scrutiny, see strategic value in reframing those into broader policy concerns.

As our research will demonstrate, the combined effects of deference by political actors to the assessments made by legal advisers, the political context in which these legal assessments are

\footnotetext{
${ }^{30}$ The exception is the House of Lords in the UK. However, its influence is diminished by the Government's willingness and ability to call upon disciplined voting of its members in the Commons to defeat amendments the Government opposes. See Hiebert \& Kelly, Parliamentary Bills of Rights ( $\mathrm{n} 15$ ) 343-344.

31 ibid, 286-288.

32 ibid.

${ }^{33}$ See BK Winetrobe, Realising the Vision: A Parliament with a Purpose (2001) 12.

${ }^{34}$ A Page, Constitutional Law of Scotland (2015) 201.

35 Page, Constitutional Law (n 34) 201-202.

36 ibid, 201; P Cairney, “Coalition and minority government in Scotland: lessons for the United Kingdom?” (2011) 82(2) PQ 261.
} 
made and the prevalence of so-called "Westminster" factors in the devolved legislature is to supplant legislative review with something qualitatively different: a form of bureaucratic review. ${ }^{37}$ This is to say that devolution's constitutional boundaries are primarily tested and protected not by the legislature but by the iterative processes that take place between officials at the various check points for legislative competence, conducted behind closed doors and under a veil of legal confidentiality. It is to our empirical examination of these processes that we now turn.

\section{The Scottish Government}

As with the requirement that UK Ministers report to Parliament on ECHR compatibility, the section 31 requirement that "the person in charge of a Bill shall, on or before introduction, state that in his view the provisions of the Bill would be within the legislative competence of the Parliament" ${ }^{38}$ serves to focus the minds of Scottish Ministers, their political advisers and officials on the question of competence at an early stage. With one proviso (to be discussed below, in relation to the role of the Lord Advocate), the assessments which support the Ministers' reporting obligation are not centralised. The exercise of competence vetting falls primarily on two of three legal offices: SGLD and the Legal Secretariat to the Lord Advocate. The third, Parliamentary Counsel's Office (PCO), is not formally responsible for ensuring that Bills are within legislative competence. ${ }^{39}$ However, with a small team of lawyers (many of whom have previously been employed within SGLD) who work on a large number of Bills, PCO has developed a keen instinct for competence issues. Whilst officials there stressed that judgement about how best to resolve those issues lies with SGLD, PCO has brought that experience to bear by offering advice in relation to individual Bills. We were told that this additional perspective has been particularly valuable where a competence issue has been missed, or where experience of recurring issues (particularly in relation to Convention rights) and how those have previously been resolved can be put to use in relation to current Bills.

\section{(1) The Scottish Government Legal Directorate}

Unlike Westminster, which operates in sessions of approximately one year and with a 12 month time limit on the passage of legislation, the Scottish Parliament operates in sessions of four years, ${ }^{40}$ with no annual cut off. It was said that this elongated parliamentary session would allow for greater flexibility within the Government's legislative programme, would encourage better scrutiny of legislation, and would avoid the loss of important Bills at the end of each parliamentary year. ${ }^{41}$ In practice, however, the Scottish Government has followed the UK Government's practice of announcing its legislative plan annually. This, it has been argued, is "a useful discipline, providing an opportunity to take stock of what has been achieved in the year just ended and what is planned for the next year," 42 but it has also been criticised on the basis that it "suggests a desire to obtain

\footnotetext{
${ }^{37}$ For more on the concept of bureaucratic review see NS Galeigh, "Neither legal nor political? Bureaucratic constitutionalism in Japanese law" (2015) 26(2) KLJ 193, citing the classic account given by NE Long,

“Bureaucracy and Constitutionalism” (1952) 46 APSR 808.

${ }^{38}$ Scotland Act 1998 s $31(1)$.

${ }^{39}$ Page, Constitutional Law (n 34) 207.

${ }^{40}$ In order to avoid a conflict with the scheduled 2020 UK General Election the Scottish Elections (Dates) Act 2016 made provision for a five year Scottish Parliament session, ending in 2021. At the time of writing there are no plans to return to the regular four year session despite the earlier than anticipated UK General Election taking place in June 2017.

${ }^{41}$ Page, Constitutional Law (n 34) 204.

42 ibid.
} 
legislation as quickly as possible" at the cost of "increased participation, more effective scrutiny, and, ultimately, "better' legislation." ${ }^{43}$ As Alan Page has said:

The absence of legislative 'sudden death' as practised at Westminster...does not mean that legislation does not generate its own pressures for delivery - from politicians who may be impatient for results and hence critical of what may seem an unnecessarily complex and time consuming process. ${ }^{44}$

Whilst there is no formal check on legislative competence built into the construction of that programme the pressure of time has had a significant effect on the vetting process. Despite the intention that the reporting obligation would require political actors to engage seriously with the question of vires we were told that, in practice, legislative competence does not rank highly in the order of Ministers' priorities. This is because concerns about competence tend not to frustrate policy objectives themselves (something which would attract the close attention of Ministers) but are more likely to relate to the ways in which those objectives can be implemented. For Scottish Ministers a more immediate and pragmatic concern is to get policy onto the statute book, and to do so without causing disruption to the legislative programme. Two consequences flow from this. First, political actors and policy officials will rarely engage directly in the process of competence vetting: this task is legally driven by officials within SGLD. An exception to this might be where a Bill presents obvious difficulties from an early stage. In those circumstances policy officials will work closely with senior lawyers within SGLD, the Legal Secretariat to the Lord Advocate and PCO to ensure that the issue is addressed in sufficient detail, which failing (and this only exceptionally) a Bill might be withdrawn from the queue for introduction. Second, where serious concerns about competence do arise, we were told that Ministers and their Special Advisers tend to be risk-averse, conceding (in the view of some officials, too readily) on contested provisions of a Bill so as to insulate the overall policy objective from queries about competence that could require additional changes, alter the Government's policy agenda or delay the Bill's introduction.

There is, then, an expectation across Government directorates to think about and address competence issues (and in particular the reserved/devolved and ECHR boundaries) as policy is being formulated. Again, there are two important consequences that flow from this. First, Government lawyers have a significant role to play in the policy-making process by advising policy officials as to how objectives can be delivered in a manner that is within the legislative competence of the Parliament. Second, the influence of Government lawyers at this stage serves to incorporate judicial norms within the process of legislative decision-making. The advice given to Ministers is based on a risk-assessment of whether - in light of the relevant jurisprudence - legislation is more likely than not to survive a legal challenge in the Supreme Court. If the answer is yes then the Minister will be advised that a Bill can be reported to Parliament as being within competence.

It is ultra vires for Scottish Ministers knowingly to introduce legislation into the Parliament that is outwith legislative competence and so legal advice weighs heavily in the mix of relevant considerations. As one official put it, the "not law" test acts as a significant constraint on what Ministers can and cannot do. Nevertheless, some elements of risk-taking endure. On the one hand, a

\footnotetext{
${ }^{43}$ ibid.

${ }^{44}$ ibid.
} 
"more likely than not" test grants to political actors the benefit of the doubt in "close call" situations. On the other hand, we were told that - as compared to the position in England \& Wales - the smaller size of the Bar, the relatively infrequent use that is made of judicial review, ${ }^{45}$ and the existence of fewer interest groups with the money or ability to raise a challenge might encourage political actors (though, it was stressed, not legal advisers) to take risks in those (very rare) situations where a provision is thought to sail close the boundary but where a post-legislative challenge appears to be unlikely. What prevents the Scottish Government from overstepping the mark here, we were told, is the role played by the Lord Advocate.

\section{(2) The Lord Advocate}

According to the Ministerial Code, a Bill "must...be accompanied by a statement, which will have been cleared with the Law Officers, that the Bill is within the legislative competence of the Scottish Parliament." ${ }^{46}$ In practice we were told that Ministers will defer to the judgement of the Lord Advocate. In order for the Law Officers to advise Scottish Ministers on competence issues, a draft Bill and a detailed note on legislative competence will be sent to the Legal Secretariat to the Lord Advocate (LSLA) (as well as to OSSP and to OAG) three weeks prior to introduction. This note will assert SGLD's view that a Bill is within the competence of the Parliament, and will form the basis of the LSLA's own assessment. This assessment is neither a perfunctory statement nor a mere formality. Frequently it will require iteration between LSLA and SGLD, typically where more explanation or clarity is needed in relation to specific provisions rather than the legislation as a whole. In rare circumstances, and in order for a certificate to be issued, action might be required on the part of SGLD to amend a Bill where serious concerns persist. Whilst on occasion there might be some pushback from SGLD in relation to the concerns expressed by LSLA we were told (1) that when the Lord Advocate reaches a view that is the end of the matter, and (2) that it is highly unlikely that Ministers themselves will push back against that view. Even where the Minister is noticeably unhappy about advice, and even where a hole is left in an important policy, it was said that Ministers will take the advice of the Lord Advocate "on the chin".

With regard to the test applied by the LSLA, officials were reluctant to identify a particular standard, but instead emphasized two important considerations that involve different forms of risk assessment. First, in relation to the specific boundaries set out in the Scotland Act, a Bill is assessed in light of its consistency with principles derived from relevant Supreme Court jurisprudence. Second, based on a civil (balance of probabilities) standard, an assessment is made of how the Supreme Court would be likely to rule on the Bill in the event of a legal challenge. Officials told us that, for LSLA, the likelihood (or not) that a Bill might later be the subject of a post-legislative challenge by a private party is not a feature of this risk assessment: this, it was said, would fly in the face of the principle of government according to law. On the contrary, we were told that the Lord Advocate would see it as a resigning matter where Ministers were knowingly to introduce legislation that is outwith competence. Several reasons were offered as to why this would be the case: first, a genuinely held belief that government is and ought to be subject to the rule of law; second, the independence imbued in the office holders by their previous careers as prosecutors or - as is currently the case - as a former Dean of the Faculty of Advocates; third, the continuing professional

\footnotetext{
${ }^{45}$ A Page, "The judicial review caseload: an Anglo-Scottish comparison" (2015) 4 JR 337.

${ }^{46}$ Scottish Government, Ministerial Code (2016) para 3.3 (emphasis added).
} 
integrity of those office holders, who might wish to pursue careers at the Bar or on the bench after they demit office. Indeed, officials across the relevant institutions pointed to the influence, the independence and the integrity of the Lord Advocate, as well as to the damaging political impact that would follow any such resignation, as a significant internal check on the introduction of an ultra vires Bill.

\section{The Scottish Parliament}

\section{(1) The Presiding Officer}

In addition to the responsible Minister, section 31 also requires the Presiding Officer to report to Parliament his or her view as to whether or not a Bill is within competence. Where the Presiding Officer reaches the view that a Bill is intra vires a "positive certificate" - a short written statement to that effect - will be included in the Bill's accompanying documents. Where the opposite conclusion is reached a "negative certificate" will instead be issued. In the event of a negative certificate (and only in the event of a negative certificate) this statement must also include the reasons for that decision. These are not expansive, identifying only the boundary or boundaries that have been crossed without revealing the legal advice that supports that view.

The Presiding Officer does not exercise a power of veto over the introduction of legislation. It is perfectly competent to introduce - and for Parliament to pass - a Bill notwithstanding a negative certificate. At the time of writing the Presiding Officer has issued four negative certificates, all in respect of Members' Bills. Of those, two - the Civil Appeals (Scotland) Bill 2006 and the Provision of Rail Passengers (Scotland) Bill 2006 - fell at stage 1, the lead subject committee having recommended that the Parliament should not agree to the general principles of the Bill. One - the Criminal Sentencing (Equity Fines) (Scotland) Bill 2008 - was withdrawn. The last (which was notable for the more detailed reasons which accompanied the Presiding Officer's certificate) - the Footway Parking and Double Parking (Scotland) Bill 2015 - was supported at stage 1 (albeit the lead committee did flag concerns about legislative competence) $)^{47}$ but ran out of time. A negative certificate, then, may not prevent the introduction of a Bill, but it does mark the start of a rocky legislative path to Royal Assent which has not yet been successfully navigated.

In order to assist the Presiding Officer in the exercise of this function a convention has emerged whereby OSSP will receive, from SGLD, a draft Bill and a note on legislative competence three weeks prior to introduction. In the event of a government Bill this will, more often than not, be the same note that is sent to the Lord Advocate (and, as we shall see, to OAG), though we were told that there may be (very rare) occasions when the Lord Advocate will be afforded the benefit of an expanded note. At this point solicitors within OSSP will begin to make their own assessment of whether or not a Bill is within competence. Whilst we were told that the note on competence is a useful point of reference, the starting point for OSSP is to read the Bill (and the supporting policy memorandum) on its own merits. This, it was said, avoids the potential for OSSP's view to be tainted by the assessments already made by SGLD and maximises the opportunity for OSSP to spot and to raise competence concerns that might have been missed during the Government's internal vetting process.

\footnotetext{
${ }^{47}$ Scottish Parliament, Stage 1 Report on the Footway Parking and Double Parking (Scotland Bill), Local Government and Regeneration Committee $\left(4^{\text {th }}\right.$ report, 2016) paras 99-104.
} 
During the three week period - and on the basis of this initial assessment - OSSP will engage in an iterative process with SGLD that (1) will inform their recommendation to the Presiding Officer, and (2) might lead to changes being made to potentially problematic legislation in order to satisfy concerns raised by the Presiding Officer and to achieve a positive certificate.

(a) Time Constraints

Officials on both sides described the time constraints of the pre-introduction phase as "challenging", with mixed views as to which side (if either) is disadvantaged as a result. Each of them point to the illusory nature of the three week period within which is included weekends, holidays, and the constituency days of the Presiding Officer and the responsible Minister. For OSSP there is an additional need to build in time for the Presiding Officer to reflect on advice, to seek further clarification from legal advisers if necessary, and to reach a view (whilst leaving time for the Scottish Government to respond to any feedback that might be offered). The (perhaps inevitable) flip side of this is that - to their frustration - SGLD will often receive feedback from OSSP relatively late in the process (perhaps as late as seven days into the pre-introduction period). Where it is clear from an early stage that competence issues might arise in relation to a Bill SGLD may choose to engage OSSP in "without prejudice" discussions about specific problematic provisions before the three week period kicks in. Moreover, it is possible - and it has happened - that where a Bill is particularly complex or where competence issues are particularly acute the three week period might be extended by the agreement of the parties concerned.

Some officials suggested to us that the constraints of the three week period work to the advantage of OSSP because, as the end of the three week period nears, anxiety about a possible negative certificate will often encourage Ministers to err on the side of caution, and to concede to the Presiding Officer's view. Such concessions might be made because the Scottish Government has been persuaded of that view. However, and it was suggested more commonly, concessions might also be made for risk-averse reasons: to ensure that the successful passage of legislation is not derailed or delayed because of subsequent pressure to pass amendments, or because of political judgements to preserve political capital for disagreements elsewhere where the stakes might be higher.

Contrary views were also expressed on both sides, however, pointing to the advantage that the Government holds by virtue of the time and resources expended on the development of a Bill, as compared to the smaller team at OSSP who come to the Bill fresh and from a standing start when it is presented to them for pre-introduction scrutiny. What is clear, however, is that the pressures of the three week period (felt on both sides) serve to focus minds sharply on the task of achieving a positive certificate. With the clock ticking, where serious disagreement continues close to the moment of introduction, the Scottish Government is - by virtue of its three week pre-introduction timetable, and by virtue of its political calculation (save in extreme and hitherto not encountered circumstances) not to proceed to introduction with a negative certificate - presented with a stark choice: to stand down, by amending or withdrawing the offending provision(s), or to face down the Presiding Officer's opposing view in the hope that he or she will give way.

(b) Scottish Government Bills 
To date, no Scottish Government Bills have been introduced with a negative certificate. However, we were told that the Government's "clean bill of health" is a poor indicator of disagreement between the Government and the Presiding Officer about legislative competence.

An average year will see in the region of 14 Bills introduced into the Parliament. Of these, officials told us that one might raise serious concerns about legislative competence, one might be considered to be a "close call", and the rest will raise no significant issues beyond perhaps a request for further information or clarification. It is rare for SGLD to receive no feedback from OSSP, who typically will seek clarity on issues that in their view have not fully been explained in the note on legislative competence. The sources of significant disagreement, however, of the sort which might give rise to "close calls" or even more serious concerns, include: the absence of case law to guide SGLD/OSSP, which then invites differences about the nature or scope of competence concerns; differences in the proportionality assessments made by each legal team in relation to Convention rights or EU law; disagreement about the necessity or adequacy of safeguards (on the face of or extraneous to the Bill) where the Government has taken/created a power; or, attempts by the Government to push at the boundary between reserved and devolved matters.

We were told that for Scottish Ministers it would be "less than ideal" and "politically awkward" to proceed to introduction with a negative certificate. Therefore, despite the fact that the Presiding Officer's decision is merely a view and not a veto on introduction, it was said that in cases where there is serious disagreement about legislative competence every effort will be made during the three week period to come to a mutually agreeable position. On the Government side this might be achieved by making amendments to or withdrawing offending provisions in order to save the overall Bill/policy or by making Pepper $v$ Hart statements regarding the exercise of powers in the chamber.

Government officials offered mixed opinions on this process. Although not a view shared across (and, it was stressed, certainly not the view of) the Scottish Government, for some a degree of frustration was expressed with regard to the frequency, the helpfulness and the "too legalistic" nature of OSSP's interventions, ${ }^{48}$ whilst others told us that risk averse Ministers (and their political advisers) have on occasion been too quick to make concessions not because they were persuaded to the Presiding Officer's view but rather for the reasons of political expediency referred to above. Indeed, a view was expressed that a more assertive approach against the objections of OSSP might have allowed the Government to be bolder in its legislative agenda without crossing the boundary of competence.

Whilst we were told that it is too strong to say that there now exists a presumption or a convention against proceeding with a negative certificate government officials said that they - and

\footnotetext{
${ }^{48}$ The example offered here is interesting for the way in which the law has developed since these interviews were conducted. A "too legalistic" approach on the part of OSSP seemed to relate primarily to their concerns where safeguards against the abuse of power are included in, for example, extraneous guidance rather than on the face of legislation. In Christian Institute v Lord Advocate [2016] UKSC 51, 2016 SLT 805 - a challenge to the Scottish Government's Named Person scheme - the inadequacy of guidance and the lack of sufficient safeguards was a crucial factor in holding that any intrusion into private and family life was not "in accordance with law" and therefore beyond the competence of the Scottish Parliament (at paras 84-85). As such, a case law driven assessment of competence may require closer attention to be paid to the place and robustness of any such safeguards.
} 
Ministers - would have to "think very carefully" about the merits of proceeding on such a basis taking into account factors such as the political importance of the policy (including the possibility of political and legal challenge in the post-introduction phase), the knock on effect for a tightly constructed legislative timetable and the political consequences of an open challenge to the Presiding Officer's judgement.

On the Parliament side we were told that officials have quickly to develop an understanding of how each Presiding Officer likes to work whilst ensuring at all times that recommendations made to them are based on robust evidence and a sound application of the relevant legal principles. Parliament officials stressed their respect for the Government's democratic mandate to pass its legislation with the consequence that in the case of very close calls - those which might be arguable either way, or where a power is capable of being exercised in a way that is intra vires - the benefit of the doubt should be afforded to the Government. This political presumption of competence chimes with a "strong"49 legal presumption of competence hardwired into the Scotland Act 1998, section 101 of which places an obligation on Courts, where it is possible to do so, to read Acts of the Scottish Parliament "as narrowly as is required...to be within competence." ${ }^{50}$ Parliament officials (and, as we shall see, counterparts in OAG) indicated that when pressed on competence concerns the Scottish Government will often - and not always persuasively - point to section 101 as something of a panacea: that no matter the concern, it will always be possible for the court to "read down" legislation so as to bring it within competence at a later date. This, it was said, might raise issues of transparency where the Government claims outwardly to be taking a power to be used in a particular (and expansive) way whilst inwardly conceding during the iterative process with OSSP that the Court might construe that power much more narrowly. When asked to identify where the tipping point might lie (the point at which serious doubt is sufficient to rebut the presumption of competence and that a recommendation should be made to the Presiding Officer to issue a negative certificate) we were told that officials will put themselves in the shoes of the Supreme Court to determine the likely outcome of any legal challenge in light of the evolving devolution jurisprudence of the court. Whilst this point has not yet been reached

Where there are entrenched views on either side officials told us that there might be - albeit rarely - an escalation in the disclosure of legal advice: on the one hand, OSSP might seek counsel's opinion, whilst on the other it is open to SGLD to reveal that their position has been reached with the support of the Lord Advocate (an exception to the convention of legal confidentiality which surrounds the advice of the Law Officers). More routinely, in these contentious cases the areas and causes of disagreement will be flagged to the Presiding Officer (we were told that a rule of thumb is that there should be "no surprises" when it falls finally on OSSP to make their recommendation) who might also require a meeting to talk these through with the Solicitor and the Team Leader responsible for the relevant Bill. Parliament officials told us that these meetings have often resulted in productive and searching questions being asked of OSSP by Presiding Officers who, even where they lack legal expertise, ${ }^{51}$ nevertheless are acutely aware of the political context in which legislation is passed and the nuances of the procedural and political hurdles that must be crossed before a Bill

\footnotetext{
49 DS v HM Advocate [2007] UKPC D1, 2007 SC (PC) 1 at para 24 per Lord Hope.

50 See Page, Constitutional Law (n 34) 263-264.

${ }^{51}$ Of the five Presiding Officers to date only the first, Sir David Steel, had a background in law, having graduated with an LLB from the University of Edinburgh before being elected to the House of Commons in 1965.
} 
is enacted. Often these discussions will result in further thought and research in order to satisfy the Presiding Officer that OSSP's view is correct (or strongly arguable).

As with the Scottish Government, the Presiding Officer is aware that the assessment of competence is a legal question made in a political context. Where there exists serious disagreement and views have become entrenched OSSP and the Presiding Officer must weigh up the reputation of the Presiding Officer and the Parliament which might be damaged by too readily assenting to legislation that is later successfully challenged, the political capital to be expended in this or that particular disagreement, the democratic mandate held by the Government and the extent to which the Bill can satisfactorily be brought within competence during the course of the legislative process. So, whilst the frustrations expressed by Government officials above betray the extent to which Ministers might back down in the face of disagreement in order to obtain a positive certificate, it is also clearly possible for a positive certificate to be issued in circumstances whereby the Presiding Officer/OSSP remain of the view that there is an appreciable risk of a later successful challenge but have themselves afforded the benefit of the doubt to the Government's view.

\section{(2) Members of the Scottish Parliament}

It can be seen that - despite having no hard legal consequences - the Presiding Officer's statutory function has created for the Scottish Parliament a space within which it can meaningfully scrutinise Bills for competence and, moreover, intervene at a stage early enough to impact upon the legislation. Nevertheless, the dynamics of the pre-introduction period have been criticised both for lacking transparency and for having a certain "chilling" effect on parliamentarians themselves. As Bruce Adamson has said, "there may be a risk that it offers a false sense of security to MSPs who may rely on the statement of competence, without having the benefit of seeing the legal advice which will have identified potential risks." ${ }^{52}$ As we have seen, effective legislative review requires that parliamentarians themselves are willing to make critical assessments of competence on its own terms. It is difficult to imagine how MSPs can engage in meaningful legislative review without the means to assess the reasons why the Presiding Officer has issued a positive certificate (which is unaccompanied by reasons) or a negative certificate (accompanied only by very limited reasons). This is all the more urgent in the context of a Parliament in which questions of competence are mainstreamed rather than being channelled through specialist committees dedicated to, and well versed in, the task of scrutinising these assessments.

Whilst there have been examples of individual MSPs introducing Members' Bills notwithstanding a negative certificate, we were told that parliamentarians in plenary and in committee will rarely second guess the decision reached by the Presiding Officer. The reasons that were offered for this were varied. First, it is a rare occurrence for legislative competence to remain a live issue at the point that MSPs engage at stage 1. As one Parliament official put it, given that most Bills are government Bills that have been subject to processes of internal scrutiny for competence (by SGLD, by the Office of the Solicitor/Presiding Officer and by the Law Officers to the Scottish and UK Governments) there is a reasonable working assumption that Bills introduced into Parliament will not be manifestly incompetent. It would be "re-inventing the wheel", and as such an inefficient use of Parliament's resources, to re-visit or to second guess that scrutiny at stage 1 . Second is the legal nature of the assessment. Whilst decisions about what action to take in light of an assessment about

\footnotetext{
${ }^{52}$ Adamson (n 26) at 203.
} 
competence are made in a political context, the application of the section 29 tests involve close analysis of the Scotland Act and related case law (both from the domestic courts as well as from the European Court of Human Rights and the Court of Justice of the European Union), of the sort that is likely to be beyond the expertise of most MSPs. So, Scottish Government officials - who queried from where Parliament would source alternative legal advice - suggested that a less binary statement on competence might serve only to create more ambiguity for Law Officers and, ultimately, a "lawyer's paradise", without making any meaningful (positive) impact on parliamentary debate. Third, it was suggested by a number of interviewees (and by officials, politicians and advisers alike) that to second guess the merits of a certificate might be seen to "lack respect for the judgement of the Presiding Officer." Finally, we were told that for backbench and opposition MSPs the policy implications of a Bill were more salient than the legal question of competence, with two possible effects: either that members take the "easy" option of deferring to the Presiding Officer on the competence question, or that they will see strategic advantage in reframing a question about legislative competence into a question about policy.

However, and as we have seen, in "close call" situations the Presiding Officer will give the benefit of the doubt to the Government. In other words, on one or two occasions each year, a Bill might reach stage 1 with a positive certificate notwithstanding the Presiding Officer's assessment undisclosed to Parliament - of a tolerable risk that (if unamended) it would not survive judicial scrutiny. On these occasions we were told that the binary nature of the Presiding Officer's statement of competence, along with the absence of reasons in support of a positive statement, can be a source of frustration. This might be alleviated by committees and their clerks being shown more of the Presiding Officer's working (in public or on a confidential basis) in relation to possible risk factors and opportunities for challenge. This, it was said, would serve a dual purpose both of assisting committees to identify witnesses who might expand upon and test those risks, and - in so doing - of informing public debate (noting that in relation to proportionality cases the inadequacy of public debate might itself play into the disproportionality test and therefore give rise to incompatibility). ${ }^{53}$ Parliament officials stressed the value of those channels of communication which do exist between OSSP and the committees and their clerks, and which are utilised on a case-by-case basis: OSSP might informally raise "risks" to legislative competence (a positive certificate notwithstanding) with a stage 1 committee/clerk as a way of pushing those issues onto the legislative agenda, whilst committees/clerks might themselves approach OSSP on a confidential basis where they (or their witnesses) have identified concerns. However, we were told that a more routine dialogue in relation to "close calls" might help to engender a more robust scrutiny of Bills by legislators. This, it was said, would help committees to identify areas of risk that could usefully be brought into the public debate: first by providing, through the identification of relevant witnesses, alternative sources of advice that might affirm, challenge or qualify Ministers' and the Presiding Officer's statements of competence; second, by breaking down the "boss mentality" that sees MSPs defer too easily to the decision of the Presiding Officer. Instead politicians should be encouraged to look behind a positive certificate where - certainly in relation to "close calls" - they might discover that a perception of risk is shared by a Presiding Officer who has nonetheless been persuaded to grant to the Government the benefit of the doubt.

\footnotetext{
53 See L Lazarus and N Simonsen, "Judicial Review and Parliamentary Debate: Enriching the Doctrine of Due Deference" in Hunt et al, Parliaments and Human Rights (n 26) ch 19.
} 


\section{E. The Law Officers}

\section{(1) The Advocate General for Scotland}

Within the Office of the Advocate General (OAG), legal advisers (themselves drawn from SGLD) will address both policy and legal issues that arise as a result of devolution. On the policy side, advisers engage with UK Government officials both to ensure that its own legislation is compliant with Scots law (what one official referred to as "putting a kilt" on UK legislation), as well as to ensure that UK Government departments understand how devolved legislation might impact upon UK policies. This latter process involves informing the relevant departments about Scottish Parliament Bills, highlighting any possible concerns, liaising between Government departments and the Attorney General's office, and making such recommendations as are necessary to the Advocate General. The Advocate General's legal advisers also focus specifically on the legal dimensions of devolved legislation: advising the Advocate General with regard to their section 33 power. Here, issues might arise either as a result of disagreement between the UK and Scottish Governments about the competence of a particular Bill or because the limits to competence constrain the Scottish Government from pursuing policies to which the UK Government has no objection (in particular where there is synergy between the policy interests of both parties). In the former case we were told that the possibility of a reference might encourage changes to the Bill that would bring it within competence. In the latter case more friendly approaches can be used, in the sense of trying to enable rather than to constrain legislative actions. The devolution settlement is an inherently fluid one in that it does not prescribe such firm boundaries as to require formal amendments to the political settlement as a whole every time legislation or the authorization for new powers is thought not strictly to be within competence. Thus section 104 of the Scotland Act 1998 allows for consequential modifications to be made to reserved law in order to accommodate Scottish legislation, section 30 allows for adjustment of the scope of devolved competence by means of an Order-in-Council, whilst the Scottish Parliament might lend its legislative consent to UK legislation in devolved areas in order to avoid the risk of legal challenge in politically contentious areas. ${ }^{54}$

Formally the Advocate General's scrutiny function is exercised at the end of the legislative process and begins with written notification from the Presiding Officer that a Bill has passed stage 3 . At this point, during the four week period between the final parliamentary stage and the submission of a Bill for Royal Assent, the Advocate General (as well as the Attorney General also on behalf of the UK Government and the Lord Advocate on behalf of the Scottish Government) may refer the Bill to the Supreme Court in order to obtain a ruling on whether or not the Bill is within the legislative competence of the Parliament. In practice, however, OAG receive the same note on legislative competence that is sent by the Scottish Government to the Lord Advocate and to the Presiding Officer during the three week pre-introduction period and will engage informally with Scottish Government counterparts as well as with relevant UK departments at that time. Indeed, we were told that the "heavy lifting" is done during the pre-introduction period when a "constructive and lengthy dialogue" about almost every Bill will identify and (if the dialogue goes well) iron out competence issues that might arise. As a result, it was said that "surprises" at the end of the process

\footnotetext{
${ }^{54}$ See A Batey and A Page, "Scotland's other Parliament: Westminster legislation about devolved matters in Scotland since devolution" [2002] PL 501. See also Lord Rodger's discussion governance in Scotland pre- and post-devolution in Martin v Most [2010] UKSC 10, 2010 SC (UKSC) 40 at paras 68-74.
} 
(during the four week period) - be that surprise on the part of the Scottish Government that a reference is seriously being considered, or on the part of the UK Government arising, for example, from a problematic stage 3 amendment - are extremely rare. One official described this as a good common sense practice, which allows for considerable exchange between OAG officials and their SGLD counterparts in order to address problems at the earliest possible stage. In this way, the dynamic between SGLD and OAG avoids the pressures of time which may exacerbate tensions between the SGLD and OSSP during the three-week period. Relations with lawyers working on these issues for the Scottish Government were characterized as professional and characterised by good will on both sides to resolve differences. We were told that generally this approach works well. However, if significant differences are not resolved and serious doubts about competence persist, the Advocate General will have to make a judgement about whether the issue should be taken to the Supreme Court.

\section{(a) Assessment criteria}

We were told that officials do not frame their advice in scientific or quantitative terms but instead exercise judgement (one official told us that counterparts in England \& Wales are more likely to use a numerical range to convey increasing or decreasing levels of risk). As is the case with SGLD and OSSP, this judgement is based on a case-based risk-assessment of the likelihood of a successful legal challenge in the Supreme Court and is made in the context of a still developing devolution jurisprudence. We were told that disagreement is most likely to arise in "close call" situations where interpretations of the relevant legal principles or case law do not speak authoritatively to the competence issue. Given the absence of any reference to date (more on which below) we were keen to discover if the UK Government exercises a degree of deference towards the Scottish Government's legislative objectives in these situations. Officials told us that this is not an appropriate way to characterize the dynamic. Instead, the context is shaped by a sense of genuine commitment to make devolution work in a manner that abides by law. Whilst officials on both sides acknowledged that the Scottish Government might on occasion sail close to the boundaries of the Parliament's competence there was also a broad agreement that this so far has been for reasons of policy (and are resolved on those terms) rather than in order to provoke conflict at the edges of the territorial constitution. Put another way: whilst it was agreed that there might be short term political capital to be gained for a devolved government (especially one of a nationalist complexion) to legislate beyond its limited competence in order to provoke a reaction from the centre, we were told that the Scottish Government takes seriously its commitment to the rule of law, that in the case of the SNP being seen to be a responsible and competent party of government is preferable to high stakes constitutional gamesmanship and that officials on both sides value the "mature" relationship that exists between the Scottish and UK Governments at official level (made easier by the crossfertilisation of Scottish Government and OAG legal advisers) and the "very good" personal relationships that have existed between the Law Officers themselves.

However, it was also suggested that in two important ways the devolution settlement favours the Scottish Government and that this must weigh in the assessment as to whether or not to issue a reference. First, the Scottish Government will routinely rely on the court's interpretative obligation in section 101 to assuage concerns that OAG might have about provisions or powers that might push the boundaries of legislative competence. For officials in OAG there was some discomfort about this, for a number of reasons: that it is "too easy" to claim that the Supreme Court 
would read a provision in a particular way; that it leaves uncertain the scope of a provision or power; and, that this uncertainty shifts the burden (and the cost) from the institutions of government to the citizen to raise a post-legislative challenge in order to make sense of that uncertainty. Second, UK Government officials expressed the view that the court's jurisprudence tends to favour the purpose of legislation as put by the proposer of the legislation, where purpose goes to the very heart of the statutory test for competence. ${ }^{55}$

\section{(b) Lack of a reference}

During the first four sessions there were (and indeed still have been) no references made by either the UK or the Scottish Law Officers. This was not inevitable. On the one hand, several officials told us that, at its outset, they believed references would be a routine feature of the devolution settlement - a vital forum for dispute resolution in a multi-layered constitution - and expressed surprise that this has not come to pass. Indeed, one senior UK Government official argued that references procedure ought still to become normalised. On the other hand, the experience in Wales has been quite different. There three references have been made: two in which legislation was upheld following a reference by the Attorney General, ${ }^{56}$ and one in which the Counsel General for Wales sought unsuccessfully to affirm competence on behalf of the Welsh Government. ${ }^{57}$ For these reasons we were keen to explore with officials across the Scottish and UK Governments whether it is appropriate to draw inferences from the lack of any reference having been made. Specifically, we asked how the absence of a reference to date has affected the criteria for assessing competence; whether or how the lack of a reference so far impacts upon the utility of the mechanism itself; and, whether and to what extent the election of a nationalist government in the Scottish Parliament has altered the way in which "close calls" are assessed.

Responses were generally consistent on whether and how the lack of a reference to date impacts on the competence exercise by both the Scottish and UK Governments. The most significant points upon which there was agreement were the following:

- Notwithstanding the absence of any reference to date, the possibility of a reference (and the fact that both sides take seriously that the prospect of a reference is a real one) is a useful resource which serves to focus minds on both sides to resolve differences during the prelegislative/legislative process.

- The warning of a possible reference is not made lightly and is used when serious differences persist about competence during the iterative process that occurs between Scottish and UK Government officials.

- There have been (one official indicated at least three) occasions in which the very real prospect of a reference has had the effect of generating amendments that ultimately have satisfied the Advocate General that no reference is required.

\footnotetext{
${ }^{55}$ On the "purpose test" in the Supreme Court's evolving devolution jurisprudence see Page, Constitutional Law (n 34) 124-130.

${ }^{56}$ Local Government Byelaws (Wales) Bill 2012 - Reference by the Attorney General for England and Wales [2012] UKSC 53, [2013] 1 AC 792; Agricultural Sector (Wages) Bill - Reference by the Attorney General for England and Wales [2014] UKSC 43, [2014] 1 WLR 2622.

${ }^{57}$ Recovery of Medical Costs for Asbestos Diseases (Wales) Bill - Reference by the Counsel General for Wales [2015] UKSC 3, [2015] AC 1016.
} 
- Whilst officials could recall no examples of legislation being allowed to pass through OAG despite the Scottish Government clearly overstepping the mark there was a feeling that some had come close.

- In those rare instances when a reference is a real possibility there is likely to be an escalation to direct engagement between the Law Officers in order to find a resolution.

- Whilst the reference is a legal mechanism the decision to make a reference is one made in a political context. This, we were told, does not alter the assessments made by officials but the political costs of making a reference will be weighed by Ministers and by the Law Officers themselves.

Although no reference has been made we were told that the prospect of a reference has been an effective means of engaging Scottish Government counterparts in a meaningful dialogue about competence. As to why no reference has been made several (often overlapping) reasons were offered:

- Impact. Officials on both sides told us that because the use of the reference had not been normalised the passage of time has served to heighten the political impact of any reference that is now made. So, in interviews, the reference was referred to as a 'nuclear' option which in itself indicates a measure to be used only in extremis.

- Engagement. Despite some reported disquiet amongst Ministers in the Scottish Government about the informal engagement of OAG during the three week pre-introduction period officials on both sides agreed that this practice is a productive one which should avoid (and so far has avoided) the need to make a reference at a later stage.

- A blunt instrument. A decision to refer a Bill to the Supreme Court will bar the Presiding Officer from submitting that Bill for Royal Assent. We were told that the inability to sever offending provisions from the Bill such that the remainder could be submitted for Royal Assent might weigh against a reference being made. In other words, the Law Officers will have to think carefully about whether it is worth, for example, delaying the passage of a complex Bill over one or two provisions that might sail close to the boundary. Whilst a recommendation has been made to "sharpen" the reference tool by allowing for severability, ${ }^{58}$ pragmatic (how to sever provisions without doing harm to the integrity of the Bill) and political (the Scottish Government has so far rejected this recommendation) hurdles have yet to be overcome.

- Political sensitivity. The election during the third and fourth parliamentary sessions of a nationalist government in Scotland (and in particular its juxtaposition with a Conservativeled coalition and then a Conservative majority UK Government) places political strain on the reference procedure that might otherwise have been used but for the risk of fanning nationalist flames. This, we were told, was particularly true around the time of the Scottish Independence Referendum when efforts to engage at an early stage and in a constructive fashion were "redoubled" in order to avoid situations which brought the UK and devolved institutions into conflict. Nevertheless, and as we have seen, officials on both sides have

\footnotetext{
${ }^{58}$ Commission on Scottish Devolution ("Calman Commission"), Serving Scotland Better: Scotland and the United Kingdom in the $21^{\text {st }}$ Century (2009) para 6.92. See the discussion in Page, Constitutional Law (n 34) 130 131.
} 
stressed that the reference procedure has not become a focal point for short term political grandstanding on either side of that broader constitutional debate.

- Working relationships. At the political level the alignment of a Labour-led coalition in Scotland and a Labour Government across the UK during the first two parliamentary sessions meant that competence concerns could be addressed relatively easily through informal channels between colleagues without recourse to a reference. Additionally, across the civil service we were told that the cross-fertilisation of Scottish Government and UK Government advisers - as well as the physical location of an OAG office within Victoria Quay - has allowed for strong and mature relationships to develop and to underpin what can on rare occasions become a fraught process.

- Remoteness. Whilst an interpretation might possibly be made that legislation encroaches upon a reserved matter, where that interpretation is strained or where the operation of the law in that way appears to be only a remote possibility, OAG might take the view that it would be inappropriate to refer the Bill during the four week period. If that remote possibility later came to pass it would be open to the possibility of a post-legislative challenge by made a third party.

Put more generally, officials were in agreement that an important part of the explanation for the lack of a reference is that the devolution settlement for Scotland represents a sophisticated and flexible political relationship that is working effectively. It has multiple points of scrutiny to address potential difficulties for competence early in the legislative process; it benefits from high calibre professionals who have established good working relationships within government and with their inter-governmental counterparts; and, it envisages flexible ways to resolve competence issues.

(c) Tipping Point

Given the range of considerations - legal and political - that influence decisions about whether to make a reference, we asked what would be the tipping point in deciding to proceed to the Supreme Court. Officials were understandably reluctant to be specific other than to suggest that a warning and a decision to proceed with a reference would ultimately require an extremely careful assessment of how the Court would be likely to rule. However in the case of very close calls the decision would be based on the broader set of considerations discussed above. Where the Advocate General is persuaded to afford to the Scottish Government the benefit of the doubt, or where a legal assessment is off-set by competing political considerations, officials pointed to the possibility of a post-legislative challenge raised by a third party as a final and significant check on vires.

Although not yet seriously contemplated, some officials indicated that the threshold for making a reference might be lowered in the event of a joint reference by both the UK and Scottish Government Law Officers, where the purpose of the reference is to bring certainty to ambiguous provisions. Indeed, it was suggested that this might be one way of "taking the sting out" of the reference mechanism in order to normalise the procedure. However, and as we shall see below, given that the risk is most significantly attached to the devolved institutions - it is their legislation at stake - there seems to be little prospect in the short to medium term that such a reference would be sought.

(2) The Lord Advocate 
As discussed above, the Lord Advocate - supported by legal advisers - will have been engaged in assessments of legislative competence, and indeed will have formed a view as to the legislative competence of a Bill, long before the commencement of the four week period. Whilst there are some (albeit rare) examples of substantial amendments being made very late in the legislative process which might carry a Bill outwith competence - the offending provision in the first successful civil challenge to an Act of the Scottish Parliament, Salvesen $v$ Riddel, ${ }^{59}$ concerned an amendment made a stage 3 and therefore out of sight of the pre-introduction scrutiny period - we were told that it is unlikely that the Lord Advocate will take a markedly different stance at this stage. Certainly, we it was said that the Lord Advocate will not easily yield to a contrary interpretation of legislative competence by one of the UK Law Officers even though, as we have seen, discussions between advisers to Scottish Government and UK Law Officers (and, if sufficiently serious or urgent, between the Law Officers themselves) have from time to time required action by one or both of the parties in order to avert a reference from being made.

Given (1) the Scottish Parliament's legislative dynamics, in which the vast majority of legislation and legislative amendments are introduced by the government, (2) the robust discussions around competence which take place during the pre-introduction period, and (3) the possibility of a reference which filters back into the legislative process at stage 2 , it is extremely unlikely that the Lord Advocate would ever feel it necessary to make a reference in order to challenge a government Bill (though officials did admit that a more likely scenario might be a reference made to challenge a Members' Bill). However, some officials did question why it was that the Lord Advocate has not yet made a reference in order to defend the Parliament's legislation. In other words, in circumstances where a post-legislative challenge by a third party seems inevitable (it seemed inevitable, for example, that legislation affecting - in their view adversely - the interests of insurers or the tobacco or drinks industries would attract litigation), it was suggested that a reference could be made by the Lord Advocate during this four week period in order to remove doubt and to protect against the damaging material and reputational consequences of such a challenge.

During the course of our interviews officials offered a number of reasons as to why this option has not yet seriously been considered. The most significant amongst these seemed to be the risk factor and the potential impact of any delay on the legislative timetable. On the one hand, legal and political advisers to the Lord Advocate and to the Scottish Ministers pointed to the risk of exposing a Bill to judicial scrutiny in order to defend a provision or provisions that the Scottish Government already believes to fall within the scope of the Parliament's powers. Indeed, officials pointed to the experience of the Counsel General for Wales - whose view that the Recovery of Medical Costs for Asbestos Diseases (Wales) Bill fell within the legislative competence of the Welsh Assembly ${ }^{60}$ was contradicted by an adverse ruling by the Supreme Court ${ }^{61}$ - as evidence of the risk inherent in making such a reference. On the other hand, and as we have seen, the Scottish Government's legislative programme is both extremely tight and planned 2-3 years in advance. Thus officials are wary of any step that might delay the implementation of legislation and of the knock on effects that a reference might have for that timetable. With regard to the Recovery of Medical Costs

\footnotetext{
59 [2013] UKSC 22, 2013 SC (UKSC) 36.

${ }^{60}$ See the letter by the Counsel General for Wales included in the account offered on the National Assembly for Wales website, available at http://senedd.assembly.wales/mglssueHistoryHome.aspx? IId=4837.

${ }^{61}$. Recovery of Medical Costs Bill reference (n 57).
} 
Bill, for example, the Counsel General for Wales wrote to the Chief Executive and the Clerk of the Welsh Assembly on December $11^{\text {th }} 2013$ indicating that he would refer the Bill to the Supreme Court. The court's judgment was returned some fourteen months later, on February $9^{\text {th }} 2015 .{ }^{62}$

In addition, two secondary considerations were offered. First, it was said that whilst some challenges are perhaps foreseeable, officials told us that there have been instances when a challenge has been raised, or has been threatened, "seemingly from nowhere". Thus it was suggested that trying to predict the unpredictable - i.e. to determine which Bills would require to be defended in this way - might not make the best use of limited resources and public money. Second, whilst officials were quick to praise the quality of the Supreme Court's jurisprudence it was suggested that something of practical value would be lost were legislation to be referred directly to that forum. This is to say that - in some officials' view - the jurisprudence of that court benefits from the prior work done by the Outer House and Inner House in post-legislative challenges, defining and sharpening the legal issues at stake.

When pressed, a fifth factor emerged: political sensitivity. We have seen that for the UK Law Officers the nationalist complexion of the Scottish Government has been a factor against making a reference, particularly against the background of the 2014 Scottish Independence Referendum. The corollary of this for the Lord Advocate is that it might be seen to be politically awkward for an SNP Government - one which has been opposed to Scottish civil appeals being decided by a UK court ${ }^{63}$ proactively to seek to defend its legislation in that forum, via a route which entirely by-passes the Scottish courts. Again, here we see the interplay of legal and political factors which shape the way in which the discretion of the Law Officers is exercised.

\section{F. CONCLUSION}

Scotland's devolution settlement offers an interesting case study for those interested in how legislative vetting for consistency with constitutional principles impacts on the process of lawmaking. On the one hand, the Scottish Parliament shares features in common with those Westminster-based systems that have adopted an innovative approach to rights protection: the marriage of judicially reviewable constitutional boundaries alongside a statutory obligation on the part of the executive to report to parliament where every Bill sits in relation to those boundaries. To this extent, the Scottish Parliament shares the fundamental challenge of promoting legislation that is consistent with constitutional values within a political environment where legislative judgement is influenced by Westminster-factors such as executive domination of parliament, the centrality of party in the organisation of how parliament functions and votes, the perpetual attempts of the opposition to demonstrate why it is the best alternative to government, and the tendency of party discipline to focus debate in binary terms: for or against the government. Indeed, this research underscores the importance of context when evaluating how legal rules and political principles influence legislative decision-making. First, the political context cannot be ignored. Judgement about

\footnotetext{
62 See the account given on the National Assembly for Wales website, here:

http://senedd.assembly.wales/mglssueHistoryHome.aspx?lld=4837.

${ }^{63}$ A position which prompted the then minority SNP government to commission the Walker Review published in 2010 - with the remit to consider the issue of the final appellate jurisdiction of the Supreme Court. N Walker, Final Appellate Jurisdiction in the Scottish Legal System (2010), available at http://www.gov.scot/Publications/2010/01/19154813/14. See B Dickinson, Human Rights and the United Kingdom Supreme Court (2013) 5-7.
} 
competence is inevitably shaped by ideological assumptions about the role of state, and thus opinions may vary within and between political parties, as well as by nationalist and unionist assumptions about the very legitimacy of the state. Second, the pressures created by the multiple sites of competence vetting are augmented by what we interpret as the preference of the Scottish Government to avoid proceeding with a Bill that could garner a negative certificate from the Presiding Officer or a reference to the Supreme Court by the UK Government. Thus, while legal advisers take great pride in their professional judgement, at the same time they are operating in an environment that might lead to political pressure to revise legislation in order to avoid these outcomes.

On the other hand, the devolution scheme departs in important ways from other jurisdictions associated with this model (such as Canada, New Zealand the United Kingdom). First, at its apex sits a strong rather than a constrained form of judicial review. Second, the devolved institutions lack full autonomy from other governments in terms of the scope of their legislative powers. Third, and perhaps most significantly, the Scotland Act requires a far more expansive range of institutional assessments of competence that combine so as to create stronger incentives than exist in other jurisdictions for the executive to revisit opinions of competence or to consider making legislative amendments. One significant exception to this pattern of cross-institutional checks is the case of amendments. Whilst legislation is subject to rigorous examination across the devolved and UK institutions during the pre-introduction period there is no mechanism for the Presiding Officer to reconsider the question of competence in light of amendments made during the passage of the Bill, nor will OAG have the benefit of prior discussion with the Scottish Government about amendments before a decision has to made whether or not to refer a Bill to the Supreme Court. If a strength of the devolution scheme is that constitutional boundaries are policed in an iterative and impactful dynamic between institutions, in the case of amendments a heavy reliance is placed on internal scrutiny of the executive by the executive, with the possibility of a reference by the Lord Advocate hanging over government amendments introduced at stage 2 .

With this said, we have seen that the plurality of these mechanisms might serve to undermine legislative review in one important sense. If an aim of such review is to create incentives whereby Ministers and MSPs anxiously scrutinise legislation for competence as well as for other policy-based concerns, the legalistic method and nature of these assessments, as well as the legal sanction which awaits incompatible legislation, is such as to dissuade political actors from challenging the legal advice which precedes them. In this way legislative review is deferred by political actors to the bureaucratic review of officials, displacing any serious, transparent and accessible political debate about the contested boundaries of legislative competence during the legislative process proper. 